\title{
Hydrogeochemical modelling of chloride mineral water from Rabka spa (Carpathian Mountains, Poland)
}

\author{
Lucyna RAJCHEL and Mariusz CZOP
}

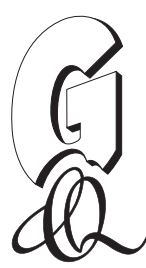

\begin{abstract}
Rajchel L. and Czop M. (2012) - Hydrogeochemical modelling of chloride mineral water from Rabka spa (Carpathian Mountains, Poland). Geol. Quart., 56 (4): 681-690, doi: 10.7306/gq.1049

Rabka has resources of chloride water, currently accessible in nine boreholes with depths from 20 to $1215 \mathrm{~m}$. The waters are of the $\mathrm{Cl}-\mathrm{Na}+\mathrm{I}+(\mathrm{Fe})$ type, and in the Rabka IG 2 borehole of the $\mathrm{Cl}-\mathrm{Na}+\mathrm{I}+21^{\circ} \mathrm{C}$ type, while their total dissolved solids (TDS) contents vary between 17.2 and $24.6 \mathrm{~g} / \mathrm{dm}^{3}$. These therapeutic waters are associated with the Carpathian flysch strata of the strongly disturbed zone of tectonic contact between the Magura Nappe with the underlying Fore-Magura Group of units. This structure is also a trap for hydrocarbons, and so strong methane $\left(\mathrm{CH}_{4}\right)$ emanations are present in Rabka both at the surface and in the boreholes providing mineral water. The strong tectonic disturbances of the study area considerably hinder the flow of underground water, extend the water resistance time at the water-rock contact and significantly limit the possibility of water exchange within the water-bearing system. Such conditions of hindered flow and limited water exchange control the unique chemical composition of the chloride water at Rabka. The components dissolved in these waters originate from the primary synsedimentary water (elision stage) accumulated in the rock matrix, from which they filter into the flow of water (infiltration stage) of various geneses, i.e., palaeoinfiltration, infiltration and dehydration, moving through the water-bearing system of the mineral water of Rabka. Modelling with the Geochemist's Workbench Standard 8.0 program has demonstrated the proposed origin of the mineral water in Rabka.
\end{abstract}

Lucyna Rajchel and Mariusz Czop, Faculty of Geology, Geophysics and Environment Protection, AGH University of Science and Technology, Mickiewicza 30,30-059 Kraków,Poland,e-mails:rajchel@geol.agh.edu.pl,mariucz@agh.edu.pl (received: April 23,2012; accepted: September 5, 2012; first published online: November 26, 2012).

Key words: Carpathians, Rabka spa, chloride groundwater, mineral and therapeutic water, hydrogeochemistry.

\section{INTRODUCTION}

Rabka is located on the drainage divide of the Poniczanka and Słonka streams (tributaries of the Raba River; Fig. 1) at a height 500-560 m a.s.1., in the Rabczańska Valley, and surrounded by the ranges of the Gorce Mts., Island Beskid Mts. and Orawa-Podhale Beskid Mts. (southern Poland), elevated some $800-1000 \mathrm{~m}$ a.s.l. About $30 \%$ of the Rabka area is covered by fir-beech forests and remnants of the Carpathian spruce forest.

Jan Długosz used the expression "Sal in Rabschyca" ("Salt in Rabschya") citing a document of Boleslas the Shy (Bolesław Wstydliwy) of 1254, in which the prince confirmed conferring the Rabka lands upon the Cistercian monks of Szczyrzyc (Franczukowski, 2008). It was already then that salt for the cloister was evaporated from the springs in the Słonka Stream valley.
The locality has obtained spa status in 2009 , and its natural riches include chloride-sodium water, having been utilized in balneotherapy since the 19th century. Rabka has also other natural advantages, particularly the excellent bioclimate, which have been investigated and observed for many years, starting in 1827 (Kozłowska-Szczęsna et al., 2002).

Rabka has currently nine working exploitation boreholes: Krakus, Rafaela, Warzelniane, Bolesław, Helena, Rabka 18, Rabka 19, Rabka IG 1 and Rabka IG 2 (Fig. 1). The water of the Helena intake is provided with a rod pump of "Konik" type (Fig. 2), the Rabka IG 2 (Fig. 3) and Rabka 18 boreholes are artesian wells, and all the remaining intakes are equipped with deep-well pumps. The water thus rendered accessible belong to the $\mathrm{Cl}-\mathrm{Na}+\mathrm{I}+(\mathrm{Fe})+(\mathrm{T})$ type with $\mathrm{TDS}$ values in the range of $17.2-24.6 \mathrm{~g} / \mathrm{dm}^{3}$ (Rajchel, 2009, 2011).

In addition to the currently used intakes, in the past there were eleven other boreholes and dug wells of mineral water of depths between 30 and $120 \mathrm{~m}$. With regard to low water yields 


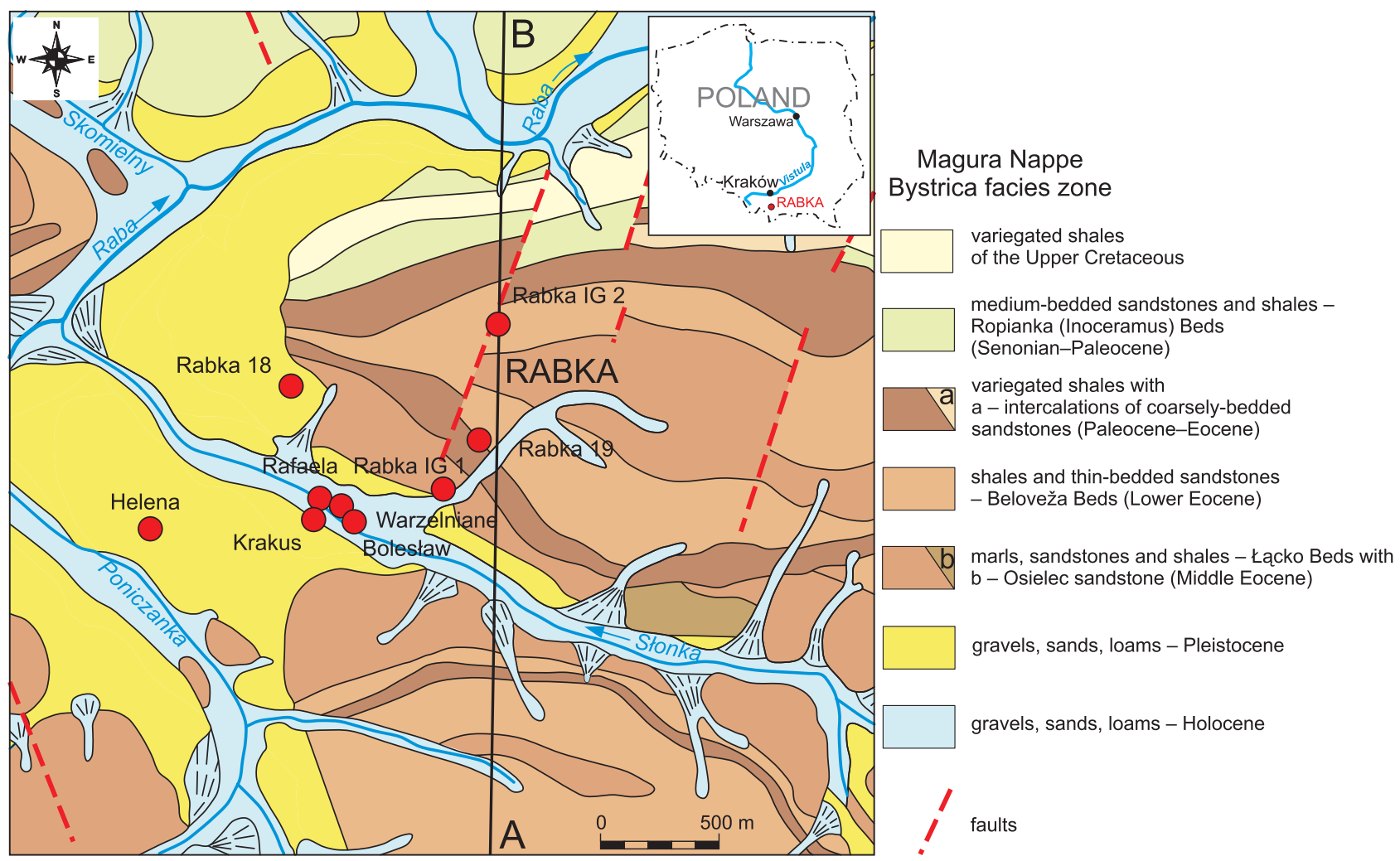

Fig. 1. Geological map of the Rabka area (after Paul and Ryłko, 1986, modified)

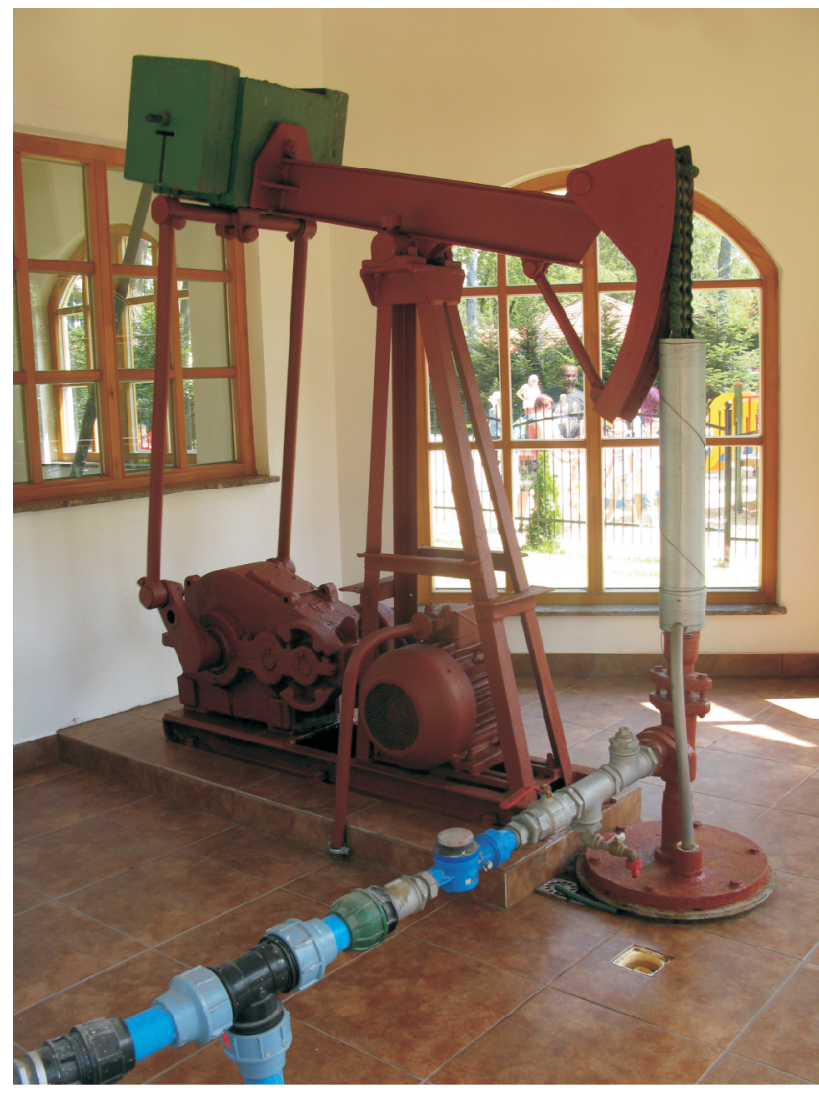

Fig. 2. Helena borehole with a rod-type "Konik" pump (photo by L. Rajchel)

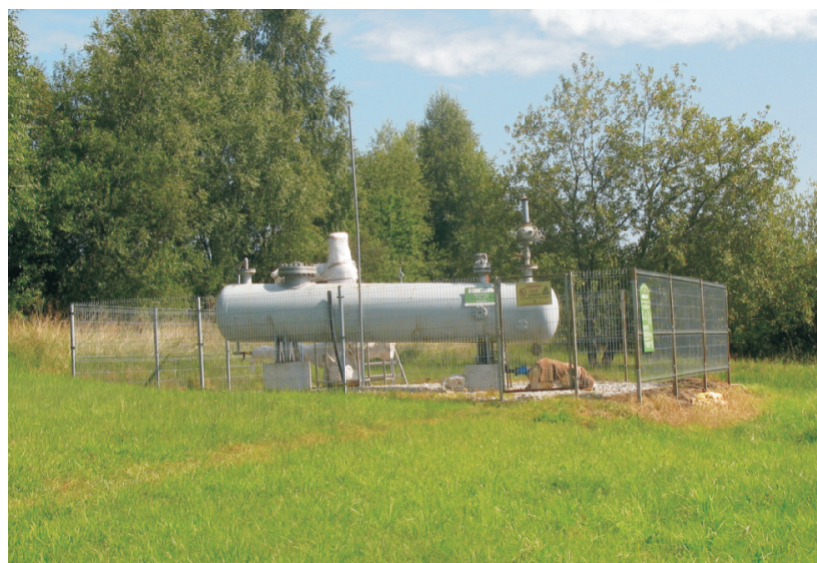

Fig. 3. Rabka IG 2 borehole with mineral and thermal water (photo by L. Rajchel)

and substantial costs of their reconstruction and further exploitation, these eleven intakes have been closed down.

$2 \mathrm{~km}$ from Rabka, in the Skomielna Biała village, a borehole of depth $1487 \mathrm{~m}$ provides water with a TDS content of $11 \mathrm{~g} / \mathrm{dm}^{3}$ and temperature $38^{\circ} \mathrm{C}$, while in Poręba Wielka village, situated $6 \mathrm{~km}$ of Rabka, the Poręba Wielka IG 1 borehole of depth $1612 \mathrm{~m}$ renders accessible water with TDS content of $19 \mathrm{~g} / \mathrm{dm}^{3}$ and temperature $42^{\circ} \mathrm{C}$.

Currently, chloride waters of Rabka with total mineralization (TDS) in the range $17.2-24.6 \mathrm{~g} / \mathrm{dm}^{3}$ are used in balneo- 


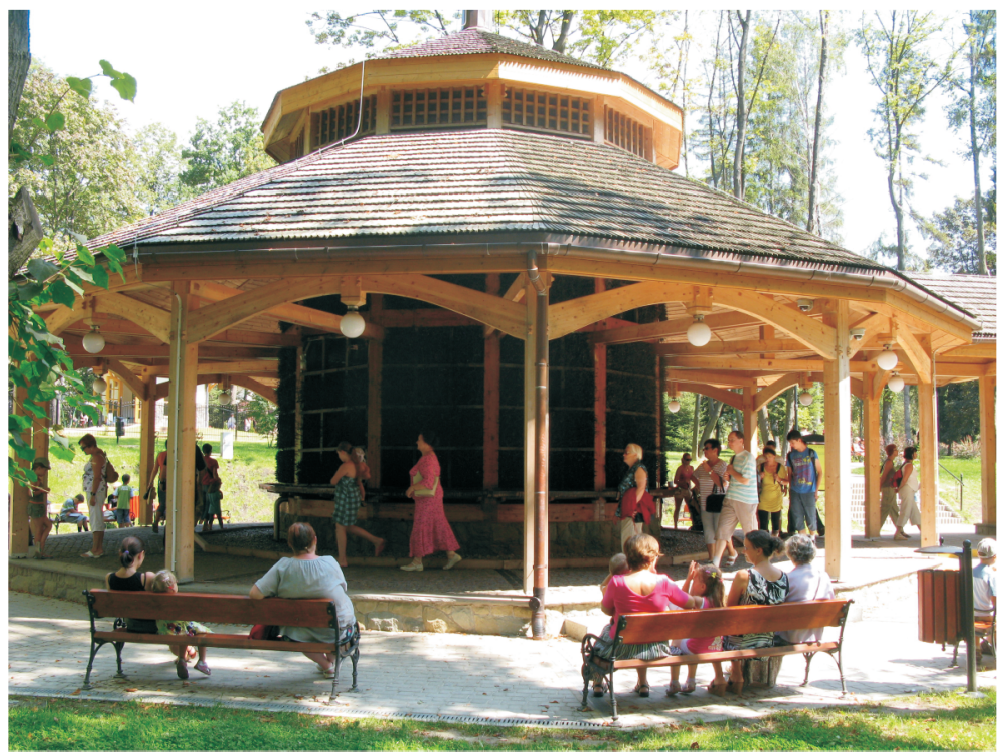

Fig. 4. Graduation tower for chloride mineral and therapeutic water in Rabka Spa (photo by L. Rajchel)

zoic rocks (Fig. 5; Birkenmajer and Oszczypko, 1989; Oszczypko et al., 2008).

In the Rabka area, the Dukla Series is represented by Oligocene, thin- and medium-bedded sandstones and shales (Krosno Beds) with a thickness of about $200 \mathrm{~m}$ (Paul and Ryłko, 1987). The sandstones are calcareous, mica-rich and interlayered with black, calcareous muddy shales. The Grybów Series is developed as Oligocene muddy shales and black marls (Grybów Beds) as well as thin-bedded sandstones (Krosno Beds) with a total thickness of about $500 \mathrm{~m}$ (Oszczypko-Clowes and Oszczypko, 2004). The prevalent shales are dark grey, locally almost black, micaceous and calcareous. The sandstones that occur as intercalations within the shales are dark grey, calcareous, finegrained, with an admixture of a pelitic material, in places with dispersed pyrite grains. The Bystrica (Nowy Sacz) facies zone is represented by Upper Cretaceous-Paleogene strata. They start with the Variegated Shales (mostly the red variety) about $150 \mathrm{~m}$ thick. The sandstones occurring within this member are medium-grained, and rich in glauconite and biotite. The Variegated Shales are overlain by thin- and medium-bedded sandstones and

therapy (medicinal bathing and inhalations) in sanatoriums and spa hospitals (Fig. 4). In 2007, following an overhaul of the wellhead, the Rabka IG 2 borehole (Fig. 3), that has the highest water reserves, was made operational: the intake provides chloride thermal water with a temperature of $21^{\circ} \mathrm{C}$. This thermal water is mixed in the central tank with cooler water from the remaining boreholes (temperatures $8-12^{\circ} \mathrm{C}$ ), which significantly lowers the heating costs of water assigned for therapy. Future plans include construction of a complex of thermal basins, based on the water from the Rabka IG 2 intake, a critical step in further spa development.

In Szczawa, not far from Rabka, carbonated waters have been exploited since 2009. The water from the Hanna, Dziedzilla, Szczawa 1 and Szczawa 2 boreholes are pumped to the drinking room of the Physiotherapeutic Facility and used in crenotherapy.

\section{GEOLOGICAL STRUCTURE OF THE RABKA AREA}

Rabka is situated in the area of the Magura Nappe in the Bystrica (Nowy Sącz) facies zone composed of sandstone-shale, Cretaceous-Paleogene flysch (Fig. 1). In the basement of the Magura Nappe, boreholes also reached Cretaceous-Paleogene strata tectonically lower units, i.e. the Grybów and Dukla units (Paul and Ryłko, 1987; Oszczypko, 1991, Oszczypko-Clowes and Oszczypko, 2004). Under the overthrusted nappes of the Outer Carpathians, at a depth of about 4-5 km, rest strata of the autochthonous Miocene that cover an unfolded platform basement comprising Upper Jurassic and Upper Paleo-

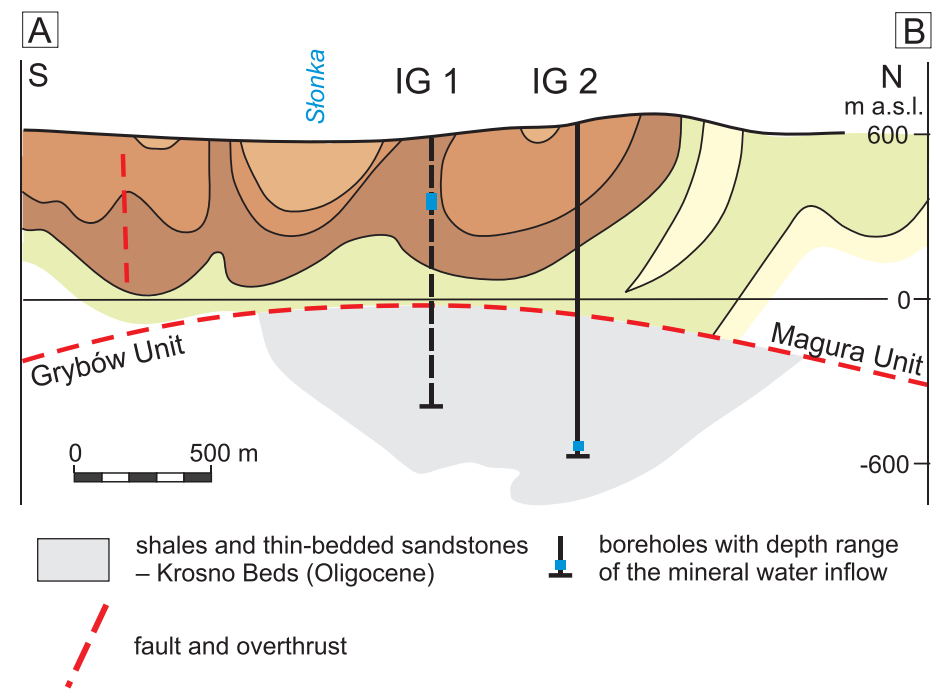

Fig. 5. Geological cross-section of the Rabka area (after Paul and Rylko, 1986, modified)

For other explanations see Figure 1 
The overlying Łącko Beds with a thickness of about $500 \mathrm{~m}$ are composed of marls, sandstones and shales. Marls prevail in the lower part of the member: they are massive, blue-grey, towards the bottom grading into sandy marls and sandstones, and towards the top into shales or siliceous marls. The sandstones are thin- and medium-bedded, massive, with a calcareous cement. The upper part of the Łacko Beds is represented mainly by marls and sandstones (Maszkowice Mbr. of the Magura Fm., see Oszczypko, 1991). The whole sequence is overlain by Quaternary strata of various thickness. These deposits include gravels, sands and alluvial loams of erosional-accumulation terraces, loess-like loams, and deluvial loams with rock rubble (Paul and Ryłko, 1987).

Rabka spa is situated within the Rabka Syncline which is secondarily folded, both on the crest and the northern limb (Słonka Stream valley; Fig. 5). To the north the syncline turns into a fault segment of the Rabka-Zaryte Anticline. The faulting within the Magura Nappe reaches probably the underlying Grybów Unit. Other tectonic disturbances are transverse dislocations, including two steep slip faults (Oszczypko, 1991; Oszczypko-Clowes and Oszczypko, 2004).

Tectonics has substantially shaped the hydrogeological conditions of the Rabka area. These conditions have been affected without doubt by the disturbed zone of the contact between the Magura Nappe and the lower-lying units. Chloride waters migrate from primary aquifers situated under the Magura Nappe, and their recharge area is located in the northern part of the Rabka Syncline (Chrząstowski, 1965)

\section{MATERIAL AND METHODS}

\section{MINERAL AND THERAPEUTIC WATER OF RABKA}

Within the area of Rabka, the mineral waters with proven therapeutic properties are of the Cl-Na type. In all the water iodine is a specific component, the content of which ranges from $21.3 \mathrm{mg} / \mathrm{dm}^{3}$ (Rabka 18 ) to $41.5 \mathrm{mg} / \mathrm{dm}^{3}$ (Bolesław). The waters rendered accessible via the Rabka IG 2 borehole are thermal, with a temperature of $28^{\circ} \mathrm{C}$ at the outlet. Their total mineralization (TDS) is from $17.2 \mathrm{~g} / \mathrm{dm}^{3}$ (Warzelniane) to $24.6 \mathrm{~g} / \mathrm{dm}^{3}$ (Rabka IG 2); they do not represent brines, however, whose TDS should exceed $35 \mathrm{~g} / \mathrm{dm}^{3}$ (although the term "brines" is often erroneously used) (Table 1). The chemical composition of the chloride water of Rabka is stable, and minor differences are probably associated with advances in analytical methods and/or temporary influx of infiltration water.

Admissible confirmed reserves of mineral therapeutic water for Rabka are $56711.6 \mathrm{~m}^{3} /$ year, of which about $21 \%$ is currently utilized. Resources of mineral water in Rabka are low, which is connected with relatively large values of the depressions around particular pumping wells (Table 2). High values of depression associated with the pumping wells are observed in a spite of the extremely low discharge rates only between $0.33-24.0 \mathrm{~m}^{3} /$ day. Estimated transmissivity of the water-bearing sandstone for these conditions typically range from $10^{-7}$ to $10^{-8} \mathrm{~m}^{2} / \mathrm{s}$, and only for the Rafaela and Rabka IG 2 boreholes were values of transmissivity of about $10^{-4} \mathrm{~m}^{2} / \mathrm{s}$ obtained. The

Physical and chemical composition of mineral water of Rabka (mg/dm $\left.{ }^{3}\right)$

\begin{tabular}{|c|c|c|c|c|c|c|c|c|c|}
\hline Parameter & Krakus & Rafaela & Warzelniane & Bolesław & Helena & Rabka 18 & Rabka 19 & Rabka IG 1 & Rabka IG 2 \\
\hline $\mathrm{pH}$ & 6.5 & 6.6 & 6.6 & 6.5 & 6.4 & 6.4 & 5.7 & 6.5 & 6.5 \\
\hline $\mathrm{T}\left[{ }^{\circ} \mathrm{C}\right]$ & 10.8 & 12.4 & 12.0 & 12.4 & 13.4 & 14.0 & 11.1 & 11.4 & 20.0 \\
\hline TDS & 24077.0 & 24138.0 & 17232.6 & 23219.0 & 18564.2 & 23565.8 & 19136.6 & 21993.2 & 24620.6 \\
\hline $\mathrm{Na}^{+}$ & 8671 & 8574 & 6075 & 8263 & 6880 & 8631 & 6851 & 8003 & 8835 \\
\hline $\mathrm{K}^{+}$ & 97.7 & 94.2 & 67.1 & 91.4 & 21.3 & 54.7 & 24.5 & 48.2 & 89.3 \\
\hline $\mathrm{Li}^{+}$ & 15.3 & 15.6 & 10.3 & 14.6 & 12.0 & 15.6 & 14.3 & 15.6 & 15.9 \\
\hline $\mathrm{Ca}^{2+}$ & 86.0 & 100.0 & 66.7 & 45.8 & 29.6 & 54.0 & 26.3 & 21.3 & 72.1 \\
\hline $\mathrm{Mg}^{+2}$ & 37.6 & 45.9 & 29.8 & 38.4 & 23.9 & 35.4 & 24.5 & 23.8 & 41.2 \\
\hline $\mathrm{Ba}^{+2}$ & 1.3 & 1.7 & 0.95 & 1.2 & 17.5 & 14.2 & 25.1 & 18.3 & 1.9 \\
\hline $\mathrm{Sr}^{+2}$ & 39.7 & 39.5 & 22.3 & 22.3 & 17.4 & 30.3 & 22.2 & 18.6 & 40.7 \\
\hline $\mathrm{Fe}^{+2}$ & 1.2 & 5.9 & 10.3 & 7.8 & 8.5 & 10.6 & 6.4 & 5.3 & 1.8 \\
\hline $\mathrm{Cl}^{-}$ & 13744 & 13939 & 9633 & 12873 & 10909 & 13390 & 10826 & 12822 & 14084 \\
\hline $\mathrm{Br}^{-}$ & 29.5 & 35.3 & 22.8 & 37.7 & 25.9 & 35.5 & 25.5 & 31.4 & 37.4 \\
\hline $\mathrm{I}^{-}$ & 25.0 & 30.6 & 30.3 & 41.5 & 21.6 & 21.3 & 21.7 & 21.9 & 25.8 \\
\hline $\mathrm{HCO}_{4}^{-}$ & 8.3 & 0.5 & 0.5 & 0.5 & 0.5 & 0.5 & 0.5 & 0.5 & 0.5 \\
\hline $\mathrm{HCO}_{3}^{-}$ & 792 & 716 & 880 & 1287 & 402 & 741 & 1018 & 616 & 829 \\
\hline $\mathrm{HBO}_{2}$ & 514.7 & 522.8 & 369.4 & 483.9 & 188.9 & 523.22 & 238.9 & 339.2 & 528.5 \\
\hline $\mathrm{H}_{2} \mathrm{SiO}_{3}$ & 12.7 & 14.4 & 11.9 & 8.0 & 4.7 & 7.2 & 8.5 & 6.6 & 16.2 \\
\hline
\end{tabular}

Analyses carried out at the Hydrogeochemical Laboratory of the Department of Hydrogeology and Engineering Geology, AGH University in Kraków, on 24 August, 2011 
The characteristics of the boreholes and mineral water resources in Rabka (data provided by UZG Rabka)

\begin{tabular}{|c|c|c|c|c|c|c|}
\hline Boreholes & $\begin{array}{c}\text { Drilled or completed } \\
\text { [years or year] }\end{array}$ & $\begin{array}{l}\text { Depth } \\
{[\mathrm{m}]}\end{array}$ & $\begin{array}{l}\text { Surface datum } \\
{[\mathrm{m} \text { a.s.l. }]}\end{array}$ & $\begin{array}{l}\text { Depth of the water } \\
\text { intake }[\mathrm{m}]\end{array}$ & $\begin{array}{l}\text { Admissible volume } \\
\text { of ground-water } \\
{\left[\mathrm{m}^{3} / \text { year }\right]}\end{array}$ & $\begin{array}{c}\text { Depression } \\
\mathrm{s} \\
{[\mathrm{m}]}\end{array}$ \\
\hline Krakus & 1855-1864 & 19.0 & 496.5 & 19.0 & 120 & 16.0 \\
\hline Rafaela & 1910 & 39.2 & 494.8 & $25-35.0$ & 7008 & 2.0 \\
\hline Warzelniane & 1912 & 50.2 & 494.8 & $41-45.7$ & - & $30.0^{*}$ \\
\hline Bolesław & 1954-1957 & 105.0 & 495.95 & 68.9-105.0 & - & $10.9^{*}$ \\
\hline Helena & 1936-1938 & 450.0 & 507.1 & $443.7-450.0$ & 876 & 200.0 \\
\hline Rabka 18 & 1966 & 120.0 & 508.33 & $118.3-120.0$ & 262.8 & 3.8 \\
\hline Rabka 19 & 1966-1967 & 95.0 & 526.24 & $60.35-85.0$ & 8760 & 93.0 \\
\hline Rabka IG 1 & $1972-1973$ & 967.1 & 512.0 & $210-260$ & - & $32.8^{*}$ \\
\hline Rabka IG 2 & 1980-1981 & 1215.0 & 564.0 & $1185-1215$ & 39420 & artesian inflow \\
\hline
\end{tabular}

* - data from the period of exploitation (for the shut-down boreholes)

conductivity of the strata with mineral waters is difficult to obtain due to the unknown thickness of the aquifer, but the expected values for this parameter are close to those of an aquitard or even of practically impermeable rocks.

Long-term data from observation of the boreholes exploitation shows a decreasing trend of water pressures. The depression for particular boreholes measured after drilling typically was much more lower than presently.

The therapeutic Rabka waters are accompanied by methane which occurs in all the boreholes in amounts from $7.7 \mathrm{mg} / \mathrm{dm}^{3}$ (Rabka 19) to $19 \mathrm{mg} / \mathrm{dm}^{3}$ (Krakus). The gas migrates from deep levels of the flysch basement through discontinuity zones (dislocations, faults, fractures) and concentrates in traps, where Quaternary gravels and sandstone rubbles are overlain by loams and clays up to several metres thick (Chrząstowski, 1965).

The chloride waters of Rabka are characterized by the presence of methane and relatively high concentrations of iodide, bromine and the acid carbonate ion, i.e., components not usually occurring in the chloride waters (brines) of salt-bearing formations, e.g., of Wieliczka or Bochnia. Thus, the Rabka water cannot result from dissolution of salt deposits (that are absent in the Carpathians), but must be associated with fossil, synsedimentary or palaeoinfiltration water. Such water usually co-occurs with oil and natural gas deposits or contains traces of these substances and are considered, therefore, as paragenetic (Dominikiewicz, 1951; Świdziński, 1954; Chrząstowski, 1965; Dowgiałło, 1976; Dowgiałło and Sławiński, 1978).

Determinations of $\delta^{18} \mathrm{O}(-5.05$ to $6.32 \%), \delta^{2} \mathrm{H}(-22.3$ to $-58.2 \%$ ) and tritium (nil to 8.9 T.U.) indicate that the waters were formed by dehydration of clay minerals during diagenesis and/or metamorphism and later mixed with infiltration water (Zuber et al., 2010). The presence of methane is linked to the bacterial breakdown of organic matter (methanogenesis) into methane and carbon dioxide. The latter gas has formed the $\mathrm{HCO}_{3}^{-}$ion in the water analysed (Leśniak and Dowgiałło, 1989; Oszczypko and Zuber, 2002; Zuber, 2007). The possible additional source of $\mathrm{CO}_{2(\mathrm{aq})}$ is connected with oxidation of methane by oxygen dissolved in water.

The mineral waters of Rabka are closely connected with the fan-shaped zone of the chloride waters, in the Outer
Carpathians (see Borysławski et al., 1980). In this zone there occurs the water with highest TDS values and also with dominant components of chloride $(\mathrm{Cl})$ and sodium $(\mathrm{Na})$, which are known in Sól (Poland) and Oravska Polhora (Slovakia) and in several deep boreholes (Borysławski et al., 1980). Mineral chloride water in these locations are connected with the deeper parts of the flysch unit - the Dukla Nappe covered by the Grybów Nappe. From the hydrogeological point of view the Dukla Nappe is a semi-closed structure without recharge. In the Dukla Nappe existing brines contain TDS above 35 $\mathrm{g} / \mathrm{dm}^{3}$ with the hydrochemical type of Cl-Na. Tectonic zones with faults or impermeable discontinuities provided the opportunity for the brines to ascend to the surface (Franko and Michalicek, 1982; Marcin, 2004; Bacova, 2009; Zakovic et al., 2009).

Total dissolved solids in the chloride mineral water in Sól reach values up to $44.3 \mathrm{~g} / \mathrm{dm}^{3}$ and in Oravska Polhora range from 42.1 to $47.3 \mathrm{~g} / \mathrm{dm}^{3}$. The $\delta^{18} \mathrm{O}$ and $\delta^{2} \mathrm{H}$ values for these brines range from -1.26 to $5.79 \%$ and from -20.1 to $-40.4 \%$, respectively, in Sól (Rajchel et al., 2004), and average 5\%o and $-20 \%$, respectively, in Oravska Polhora (Zakovic et al., 2009).

Relatively high TDS are also observed for mineral water in deeper boreholes in Szczawa and range between $4.5 \mathrm{~g} / \mathrm{dm}^{3}$ (Dziedzilla) and $17.2 \mathrm{~g} / \mathrm{dm}^{3}$ (Szczawa 2). Mineral water is of the hydrochemical type $\mathrm{HCO}_{3}-\mathrm{Cl}-\mathrm{Na}$, and contains gaseous $\mathrm{CO}_{2}$ in concentrations from 1.3 to $3.6 \mathrm{~g} / \mathrm{dm}^{3}$. Mineral waters in Szczawa are also accessible from a few springs (Gardonie, Głębieniec, Pod Jabłonią and Tereska), with lower TDS between 1.2 and $3.5 \mathrm{~g} / \mathrm{dm}^{3}$ and hydrochemical type $\mathrm{HCO}_{3}-\mathrm{Na}-\mathrm{Ca}$. The mineral water origin in Szczawa is connected with the complicated geology of this area (Szczawa tectonic window) and occurrence of faults that can conduct water from deeper parts of the flysch strata to the surficial zone (Chrząstowski, 1971).

\section{HYDROGEOCHEMICAL MODELLING}

Hydrogeochemical data from the Rabka mineral waters were interpreted using the Geochemist's Workbench (GWB) 
program in its Standard 8.0 version. This application represents one of the best programs in hydrogeochemical modelling, combining the features of a calculation sheet of hydrochemical data with a group of advanced programs for geochemical calculations and creating specialized graphs (e.g., Eh-pH diagrams). A wide range of thermodynamic databases and the possibility of carrying out calculations of activity coefficients of dissolved phases in the case of the solutions of both low and very high ionic strengths is a particular advantage of the GWB program (Bethke, 2008).

The process of replacing the primary fluid with a composition approaching that of sea water was imitated by the modelling using the React program, which is an element of the packet of applications included within the Geochemist's Workbench program. For the conditions occurring in the Rabka area, the "flush" model was selected, as it provides the possibility of determining the hydrogeochemical consequences of replacing the primary fluid that infills the water-bearing system by successive portions of an aqueous solution with a random composition (Bethke, 2008). This model is thus very well suited to imitating the infiltration stage, i.e., replacing a highly mineralized solution of the altered synsedimentary water by a stream of water of lower mineralization.

The modelling of the water-bearing system of the Rabka mineral water was carried out for a volume of about $0.1 \mathrm{~m}^{3}$ of sandstone of the Carpathian flysch, imitated by $250 \mathrm{~kg}$ of quartz containing $1 \mathrm{~kg}$ of water (porosity $\mathrm{n}=1 \%$ ).

\section{INTERPRETATION \\ OF HYDROGEOCHEMICAL DATA}

All the mineral waters accessible at Rabka are characterized by their chloride-sodium (Cl-Na) hydrogeochemical type. Sodium and chlorides dominate among dissolved constituents and make up to $96.4-97.9 \%$ of cations and $94.3-97.7 \%$ of anions, respectively. Most of the remaining constituents have concentrations in the range from $\sim 1 \mathrm{mg} / \mathrm{dm}^{3}$ to several tens $\mathrm{mg} / \mathrm{dm}^{3}$. Only in the case of boron (expressed as metaborate acid $\mathrm{HBO}_{2}$ ) and acid carbonate $\left(\mathrm{HCO}_{3}^{-}\right)$are their concentrations higher: $\mathrm{HBO}_{2}$ from 188.9 to $528.5 \mathrm{mg} / \mathrm{dm}^{3}$, and $\mathrm{HCO}_{3}^{-}$from 402 to $1287 \mathrm{mg} / \mathrm{dm}^{3}$. Such significant concentrations of the acid carbonate ion in chloride water with high TDS values are very rare.

The mineral waters at Rabka are similar with regard to their total mineralization. According to current data (available as of August, 2011), the TDS values range from $17.2 \mathrm{~g} / \mathrm{dm}^{3}$ (Warzelniane) to $24.6 \mathrm{mg} / \mathrm{dm}^{3}$ (Rabka IG 2) (Fig. 6).

Another common feature of the Rabka waters is a general constancy of their chemical composition during exploitation. Geochemical data, available in most cases since the end of 1940s or since the mid-1960s, indicate that the range of variability of physical and chemical water parameters is narrow. The box-plot graphs of the chloride concentrations show small oscillations and normal distributions of the values recorded (Fig. 7).

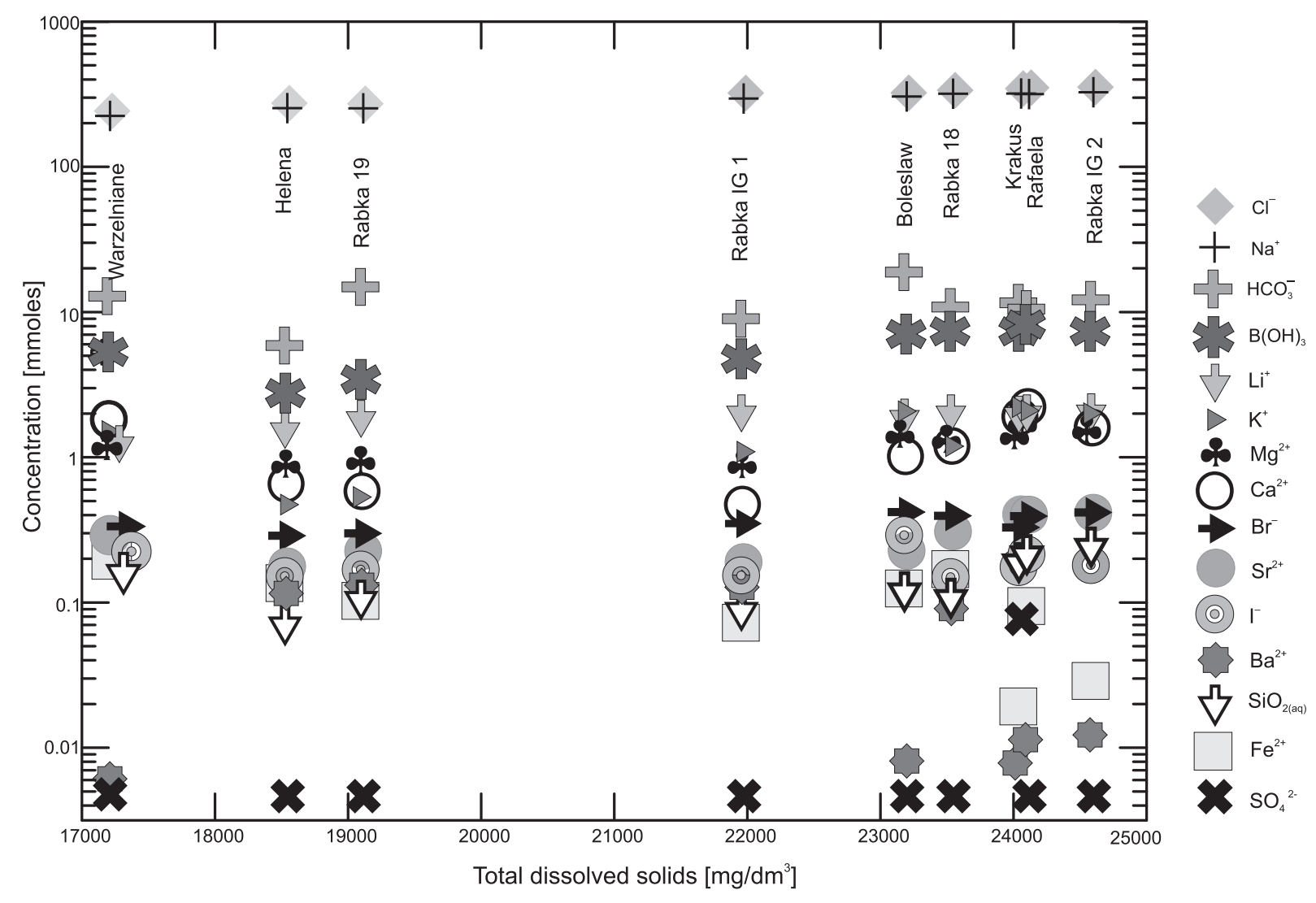

Fig. 6. Chemical composition of the mineral water from Rabka 

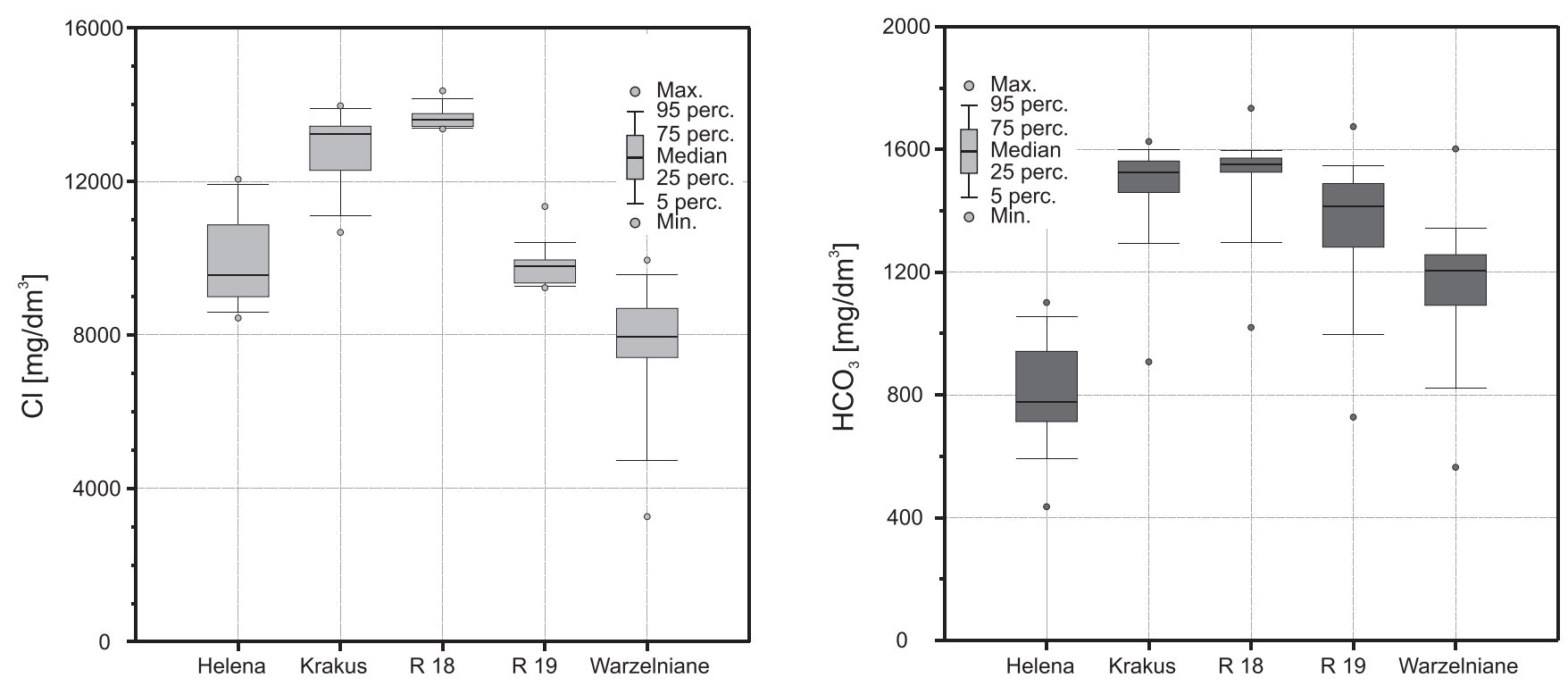

Fig. 7. Box and whiskers plots for mineral water from Rabka

Modelling of the conditions in which the chemical composition of the Rabka mineral waters evolved was made for an aqueous solution with a composition corresponding to that of sea water and occurring within sandstone layers of the flysch strata. Such water was transformed (altered) in the processes of membrane filtration: its total mineralization (TDS) increased and when it became oversaturated $(\mathrm{SI}>0)$ very weakly soluble carbonate and sulphate minerals started to precipitate. Then, water migrating within the modelled sandstone, containing the carbonate precipitates (mainly calcite $\mathrm{CaCO}_{3}$ ), could further change these into dolomite, according to the reaction:

$$
\mathrm{Mg}^{2+}+2 \mathrm{CaCO}_{3} \leftrightarrow \mathrm{CaMg}\left(\mathrm{CO}_{3}\right)_{2}+\mathrm{Ca}^{2+}
$$

The reaction above proceeds under typical conditions with a mass deficit, i.e., in the reaction of $1 \mathrm{~kg}$ of an aqueous solution enriched in magnesium in place of a higher amount of dissolved calcite $(17.5 \mathrm{mmol})$ a lower amount of dolomite forms $(8.7 \mathrm{mmol})$ (Bethke, 2008). The process presented is probably responsible for lowering the concentrations of calcium and magnesium in the synsedimentary water, altered as a result of diagenesis.

The next process crucial in the formation of the chemical composition of the Rabka mineral water is associated with oxidizing of methane trapped in the flysch strata, and disturbed by folding and faulting. In the Rabka area methane migrates to near-surface strata, where at the contact with oxygenated water the following reaction takes place:

$$
\mathrm{CH}_{4(\mathrm{aq})}+2 \mathrm{O}_{2(\mathrm{aq})} \leftrightarrow \mathrm{HCO}_{3}^{-}+\mathrm{H}^{+}+\mathrm{H}_{2} \mathrm{O}
$$

The process provides, to the flow of mineral water, constant amounts of bicarbonate anions and - additionally - it produces hydrogen cations that increase corrosion of the rocks composing the aquifer, and particularly of the carbonate minerals precipitated during diagenesis.

Another fundamental process in controlling the chemical composition of the Rabka mineral water involves replacing pri-

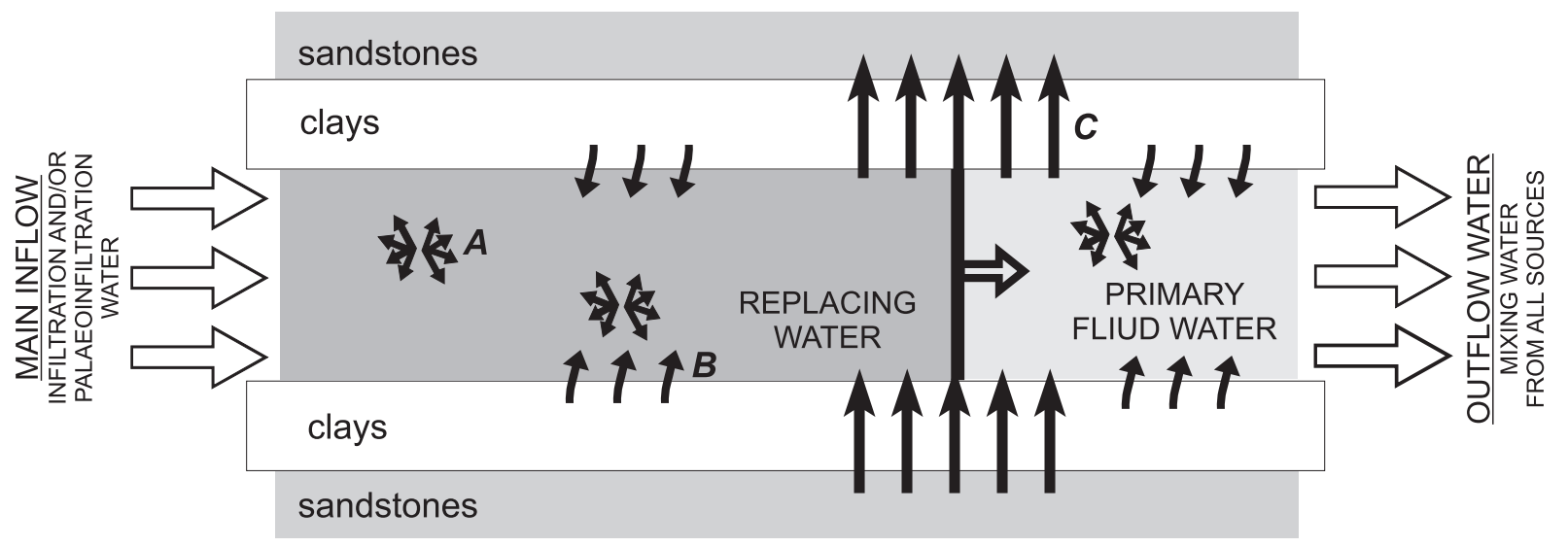

Fig. 8. Conceptual model for the modelled groundwater system

A - dehydration water-internal, B - dehydration water-external, C - water from ultrafiltration $\left(\mathrm{C}_{\text {inflow }}=\mathrm{C}_{\text {oufflow }}\right)$ 
mary fluids, i.e., synsedimentary sea water altered as a result of diagenesis, by the total fluid flow recharging the water-bearing system. As the results of isotopic investigations indicate, this flow may be composed of a mixture of infiltration, palaeoinfiltration and dehydration water, and also the water removed from the pore space of the rocks during diagenesis (drain-off from the rock as a result of ultrafiltration in clay-rich layers due to the compaction of strata under the pressure of overburden) (Fig. 8).

The chemical composition of the starting primary fluid is shown in Table 3. The initial fluid composition does not depart from that of average sea water (after Drever, 1988) except for the concentrations of calcium $\left(\mathrm{Ca}^{2+}\right)$, magnesium $\left(\mathrm{Mg}^{2+}\right)$ and sulphates $\left(\mathrm{HCO}_{4}^{-}\right)$, as these ions were removed from the fluid by precipitating carbonates and sulphates. The primary fluid with a mass of $1 \mathrm{~kg}$ was replaced in the given period of $10 \mathrm{Ma}$ with $1 \mathrm{~kg}$ of pure water, not containing dissolved solids. The additional provisos included a constant influx of dissolved carbon dioxide $\mathrm{CO}_{2 \text { (aq) }}$ generated by oxidation of methane and a dissolution of minor amounts of calcite $\left(\mathrm{CaCO}_{3}\right)$ and dolomite $\left[\mathrm{CaMg}\left(\mathrm{CO}_{3}\right)_{2}\right]$.
The results of the modelling are presented in Table 4 and diagrams (Figs. 9 and 10). In such a hypothetical case, the results show that water with a composition close to that of the Rabka mineral water could be formed by replacing the primary, highly mineralized solution via alteration of synsedimentary water by a flow of water with lower mineralization. Such a process requires some millions years, when the amount of the water added into the water-bearing system is about $40-70 \%$ of the primary fluid volume.

\section{CONCLUSIONS}

The mineral waters of Rabka were formed under complex geological conditions, in a tectonically affected zone. As a result of folding and faulting of the Carpathian flysch, a trap for hydrocarbons was formed, shown by strong emanations of methane both from the wells providing mineral water and directly on the ground surface in the central part of the Słonka Stream valley. The structure of the trap represents a zone impeding the flow of underground water, making replacement of

T a b 1 e 3

Chemical composition of the primary fluid

\begin{tabular}{|l|c|c|}
\hline \multicolumn{1}{|c|}{ Constituent } & Unit & Value \\
\hline $\mathrm{H}_{2} \mathrm{O}$ & $\mathrm{kg}$ & 1 \\
\hline quartz $\left(\mathrm{SiO}_{2}\right)$ & $\mathrm{kg}$ & 250 \\
\hline $\mathrm{pH}$ & - & 7 \\
\hline $\mathrm{Na}^{+}$ & $\mathrm{mg} / \mathrm{kg}$ & 19000 \\
\hline $\mathrm{K}^{+}$ & $\mathrm{mg} / \mathrm{kg}$ & 390 \\
\hline $\mathrm{Ca}^{2+}$ & $\mathrm{mg} / \mathrm{kg}$ & 40 \\
\hline $\mathrm{Mg}^{2+}$ & $\mathrm{mg} / \mathrm{kg}$ & 24 \\
\hline $\mathrm{Sr}^{2+}$ & $\mathrm{mg} / \mathrm{kg}$ & 8 \\
\hline $\mathrm{Cl}^{-}$ & $\mathrm{mg} / \mathrm{kg}$ & 10500 \\
\hline $\mathrm{Br}^{-}$ & $\mathrm{mg} / \mathrm{kg}$ & 67 \\
\hline $\mathrm{HCO}_{3}^{-}$ & $\mathrm{mg} / \mathrm{kg}$ & 142 \\
\hline
\end{tabular}

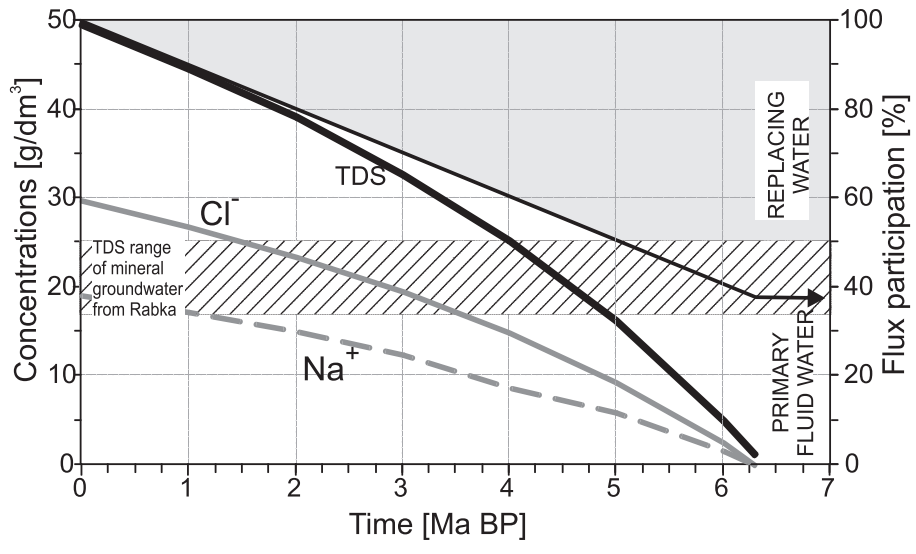

Fig. 9. Temporal changes of the TDS, sodium and chlorides concentration in the modeled groundwater system

Chemical evolution of the primary fluid in the modelled system

\begin{tabular}{|c|c|c|c|c|c|c|c|c|}
\hline $\begin{array}{l}\text { Time } \\
{[\mathrm{My}]}\end{array}$ & $\begin{array}{l}\text { Mass of added } \\
\text { water }[\mathrm{g}]\end{array}$ & $\begin{array}{l}\mathrm{pH} \\
{[-]}\end{array}$ & $\begin{array}{c}\text { Ionic } \\
\text { strenght } \\
{[-]}\end{array}$ & $\begin{array}{c}\text { TDS } \\
{\left[\mathrm{g} / \mathrm{dm}^{3}\right]}\end{array}$ & $\begin{array}{c}\mathrm{Cl} \\
{\left[\mathrm{g} / \mathrm{dm}^{3}\right]}\end{array}$ & $\begin{array}{c}\mathrm{Na} \\
{\left[\mathrm{g} / \mathrm{dm}^{3}\right]}\end{array}$ & $\begin{array}{c}\mathrm{HCO}_{3} \\
{\left[\mathrm{mg} / \mathrm{dm}^{3}\right]}\end{array}$ & Water type \\
\hline 0 & 0.0 & 7.00 & 0.878 & 49.4 & 29.7 & 19.0 & 142 & $\mathrm{Cl}-\mathrm{Na}$ \\
\hline 1 & 100.0 & 6.72 & 0.787 & 44.5 & 26.7 & 17.1 & 233 & $\mathrm{Cl}-\mathrm{Na}$ \\
\hline 2 & 200.0 & 6.64 & 0.684 & 39.0 & 23.3 & 14.9 & 335 & $\mathrm{Cl}-\mathrm{Na}$ \\
\hline 3 & 300.0 & 6.61 & 0.568 & 32.6 & 19.4 & 12.4 & 453 & $\mathrm{Cl}-\mathrm{Na}$ \\
\hline 4 & 400.0 & 6.61 & 0.434 & 25.2 & 14.8 & 8.7 & 591 & $\mathrm{Cl}-\mathrm{Na}$ \\
\hline 5 & 500.0 & 6.63 & 0.275 & 16.2 & 9.3 & 5.9 & 757 & $\mathrm{Cl}-\mathrm{Na}$ \\
\hline 6 & 600.0 & 6.71 & 0.081 & 5.0 & 2.4 & 1.5 & 965 & $\mathrm{Cl}-\mathrm{Na}$ \\
\hline 6.3 & 629.0 & 9.79 & 0.017 & 1.2 & 0.00002 & 0.00002 & 1040 & $\mathrm{HCO}_{3}-\mathrm{Ca}$ \\
\hline
\end{tabular}


the water in the water-bearing system more difficult and thus significantly extending the time of the water-rock contact.

The composition of the Rabka mineral water is a result of interconnected hydrogeochemical processes. The essential feature is replacing of the primary fluid that originated by altering synsedimentary water due to diagenetic processes by flow of less mineralized water. The waters flowing into the water-bearing system have different geneses: according to isotopic investigations they are water of the infiltration or palaeoinfiltration, dehydration and also diagenetic in character. The water of the hydrogeochemical infiltration stage flowing into the relatively close system of the mineral waters of Rabka replace (dilute) the primary, post-diagenetic fluid formed during the elision stage. The components deposited during this stage within the low-permeability rocks surrounding the water-bearing system of the Carpathian sandstones may represent an additional source of dissolved solids.

The succeeding processes important in the formation of the unique composition of the Rabka mineral water involve inflow of carbon dioxide or/and slow oxidation of methane in water (by water-dissolved oxygen) that results in generating bicarbonate anions $\left(\mathrm{HCO}_{3}^{-}\right)$and hydrogen cations $\left(\mathrm{H}^{+}\right)$thus acidifying the aqueous environment. Such water with decreased $\mathrm{pH}$ values are more aggressive in respect to surrounding rocks of the aquifer and more rapidly dissolve carbonate minerals (calcite and dolomite).

Modelling with the Geochemist's Workbench Standard 8.0 program has shown that the chemical composition of the mineral water of Rabka is associated with a zone of impeded water flow. The calculations involving compositional changes of a hypothetical, only slightly modified average sea water, have led to a characteristic chloride mineral water of composition

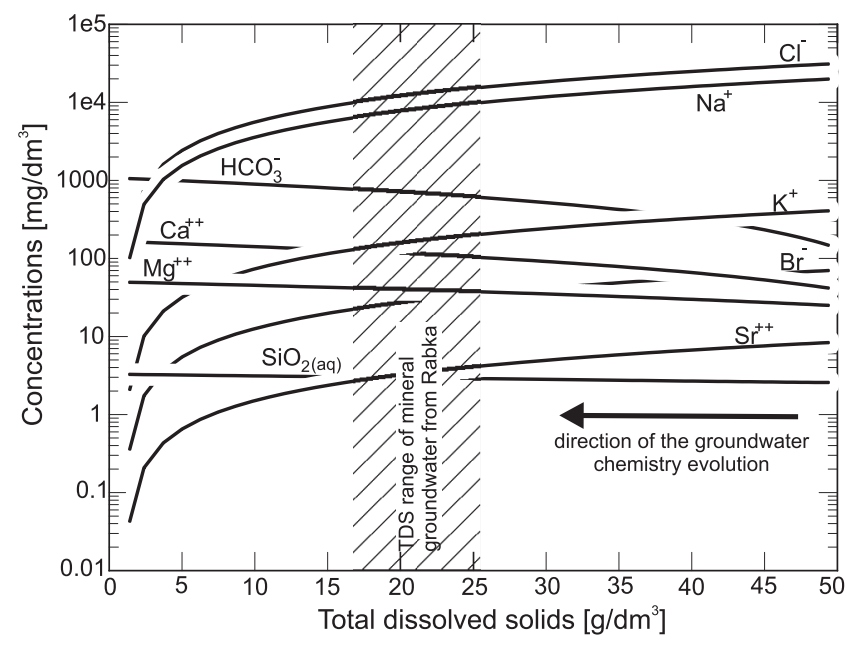

Fig. 10. Concentration changes of the selected constituents dissolved in the modelled groundwater

close to that of the Rabka chloride water. Generation of water of such a composition is a long-lasting process (it requires several million years) by slow exchange of water in the water-bearing system, during which time the amount of the water with lower mineralization is about $40-50 \%$ of the strongly mineralized primary fluid volume.

Acknowledgements. Research was supported by the AGH University of Science and Technology, grant no. 18.18.140.939 (Nr N N307 312439). We thank anonymous reviewers and Prof. N. Oszczypko for useful suggestions and editorial changes which improved the manuscript.

\section{REFERENCES}

BACOVA N. (2009) - Significance of the graphic analysis of hydrogeochemical data for interpretation of origin of mineral water of Flysch Belt and Foredeep of Western Carpathians (in Slovak with English summary). Miner. Slov., 41: 225-242.

BETHKE C. (2008) - Geochemical and biogeochemical reaction modeling. 2nd ed. Cambridge University Press.

BIRKENMAJER K. and OSZCZYPKO N. (1989) - Cretaceous and Paleogene lithostratigraphic units of the Magura Nappe, Krynica Subunit, Carpathians. Ann. Soc. Geol. Pol., 59 (1-2): 145-181.

BORYSŁAWSKI A., OSZCZYPKO N. and TOMAŚ A. (1980) - Chemical composition of Carpathian saline waters - a statistical analysis. Biul. Państw. Inst. Geol., 323: 57-86.

CHRZĄSTOWSKI J. (1965) - The phenomena of methane exhalations on the ground of geological structure in the health resort of Rabka (in Polish with English summary). Zesz. Nauk. AGH, 81 (6): 75-100.

CHRZĄSTOWSKI J. (1969) - Wody mineralne Rabki. Spraw. Pos. Kom. PAN Oddz. w Krakowie, 13 (2): 576-580.

CHRZAূSTOWSKI J. (1971) - Wody mineralne Szczawy na tle budowy geologicznej. Problemy zagospodarowania ziem górskich. Komitet Zagospodarowania Ziem Górskich PAN, 9: 100-136.
DOMINIKIEWICZ M. (1951) - Wody mineralne Polski. Państw. Zakł. Wyd. Leśnych, Warszawa.

DOWGIAŁŁO J. (1976) - Problems of the origin of Cl- $\mathrm{HCO}_{3}-\mathrm{Na}$ mineral waters of the Polish flysch Carpathians. In: Proceedings of the International Symposium on Water-Rock Interaction, Czechoslovakia 1974. Geological Survey, Prague: 12-22.

DOWGIAŁŁO J. and SŁAWIŃSKI A. (1978) - Remarks on the origin of saline ground waters at Rabka. In: Hydrogeochemistry of Mineralized Waters (eds. B. Słowańska, Z. Pakulska): 195-203. Proceedings of the IAH Conference of Cieplice Spa (Poland), 1978. Inst. Geol., Warszawa.

DREVER J. I. (1988) - The geochemistry of natural water. 2nd ed. Prentce-Hall.

FRANCZUKOWSKI Z., ed. (2008) - The Great Book of Polish Spas, Seaside resorts and places with Spa-climatic Qualities (in Polish with English summary). Wyd. Mirex, Bydgoszcz.

FRANKO O. and MICHALICEK M. (1982) - Jodobromove vody Slovenska. Zapadne Karpaty, seria hydrogeologia a inzinierska geologia. Geologický ústav Dionýza Štúra, Bratislava, 4: 97-133. 
KOZŁOWSKA-SZCZESNA B., ed. (2002) - Bioklimat uzdrowisk polskich i możliwości jego wykorzystania w lecznictwie. AN IG i PZ im. S. Leszczyckiego, Warszawa.

LEŚNIAK P.M. and DOWGIAŁŁO J. (1986) - About genesis of chloride water in Carpathians. The polemics (in Polish with English summary). Prz. Geol., 34 (7): 394-398.

MARCIN D. (2004) - Conditions of formation mineral waters in Sarissky Stiavnik and Radoma. Env. Geol., 46: 646-650.

OSZCZYPKO N. (1991) - Stratigraphy of the Palaeogene deposits of the Bystrica Subunit (Magura Nappe, Polish Outer Carpathians). Bull. Pol. Acad. Sc., Earth Sc., 39: 415-431.

OSZCZYPKO-CLOWES M. and OSZCZYPKO N. (2004) - The position and age of the youngest deposits in the Mszana Dolna and Szczawa tectonic windows (Magura Nappe, Western Carpathians, Poland). Acta Geol. Pol., 54: 339-407.

OSZCZYPKO N. and ZUBER A. (2002) - Geological and isotopic evidence of diagenetic water in the Polish Flysch Carpathians. Geol. Carpath., 53 (4): 1-13.

OSZCZYPKO N., ŚLACZKA A. and ŻYTKO K. (2008) - Tectonic subdivision of Poland: Polish Outer Carpathians and their foredeep (in Polish with English summary). Prz. Geol., 56 (10): 927-935.

PAUL Z. and RYŁKO W. (1986) - Szczegółowa mapa geologiczna Polski 1:50 000, ark. Rabka. Wyd. Geol., Warszawa
PAUL Z. and RYŁKO W. (1987) - Objaśnienia do Szczegółowej mapy geologicznej Polski 1:50 000, ark. Rabka. Wyd. Geol., Warszawa, $1-89$.

RAJCHEL L (2009) - Occurrences and utilization of chloride water in Rabka spa (in Polish with English summary). Geologia, 35 (2/1): 271-278.

RAJCHEL L. (2011) - Utilization of geothermal water in the Rabka spa in Polish with English summary). In: Atlas of Geothermal Water and Energy Resources in the Western Carpathians (ed. W. Górecki): 148-151. Ministerstwo Środowiska.

RAJCHEL L., ZUBER A., DULIŃSKI M. and RAJCHEL J. (2004) - Occurrences and genesis of chloride waters in Sól (S Poland) (in Polish with English summary). Prz. Geol., 52 (12): 1179-1186.

ŚWIDZIŃSKI H. (1954) - Zagadnienia geologiczne wód mineralnych w szczegółności na Niżu Polskim i w Karpatach. Materiały pozjazdowe Zjazdu Naukowo-Technicznego w Krynicy w roku 1954. Katowice: 33-73.

ZAKOVIC M., POTFAJ M., FENDEK M. and BODIS D. (2009) - Iodine-brome groundwater in the area of Oravska Polhora (in Slovak with English summary). Podzemna Voda, 15 (2/2009): 230-239.

ZUBER A., ed. (2007) - Metody znacznikowe w badaniach hydrogeologicznych. Oficyna Wyd. PWroc., Wrocław.

ZUBER A., CHOWANIEC J. and BOROWIEC M. (2010) - On the origin of chloride waters in the Polish Flysch Carpathians (in Polish with English summary). Biul. Państw. Inst. Geol., 441: 201-208. 